\title{
Phytoprotection
}

\section{Hommage au Dr Gilles Émond Tribute to Dr Gilles Émond}

\section{Richard Hogue}

Volume 87, numéro 1, avril 2006

URI : https://id.erudit.org/iderudit/013963ar

DOI : https://doi.org/10.7202/013963ar

Aller au sommaire du numéro

Éditeur(s)

Société de protection des plantes du Québec

ISSN

0031-9511 (imprimé)

1710-1603 (numérique)

Découvrir la revue

Citer ce document

Hogue, R. (2006). Hommage au Dr Gilles Émond. Phytoprotection, 87(1), 1-4.

https://doi.org/10.7202/013963ar d'utilisation que vous pouvez consulter en ligne.

https://apropos.erudit.org/fr/usagers/politique-dutilisation/ 


\title{
Hommage au Dr Gilles Émond
}

\begin{abstract}
Allocution de Monsieur Richard Hogue présentée en hommage à Monsieur Gilles Émond pour ses services à titre de rédacteur en chef de la revue Phytoprotection lors de la $97^{\circ}$ réunion annuelle de la Société de protection des plantes du Québec (SPPQ) tenue les 9 et 10 juin 2005 à Gatineau, Québec, Canada.
\end{abstract}

Je remercie le conseil d'administration de la SPPO pour l'opportunité qu'il m'offre de rendre hommage à Monsieur Gilles Émond pour son travail bénévole de rédacteur en chef de la revue Phytoprotection réalisé depuis 10 ans.

Je vous présente d'abord quelques notes biographiques qui vous aideront à mieux connaître la carrière de scientifique et de gestionnaire de Monsieur Émond :

- Après avoir complété sa formation d'agronome à I'Université de Montréal en 1958, Monsieur Émond entrait en fonction au ministère de l'Agriculture, des Pêcheries et de I'Alimentation du Québec (MAPAQ). Il y travaillera pendant 36 ans.

- De 1962 à 1968, il complétait successivement ses études de maîtrise et de doctorat en malherbologie à I'Université McGill. Son projet de maîtrise portait sur le mode d'action du linuron utilisé en préémergence, tandis que sa thèse de doctorat s'intitulait : L'absorption et la distribution du linuron dans le haricot et son action sur la photosynthèse et la respiration.

- En 1965, Monsieur Émond était maître d'œuvre de la conception et de la présentation du premier cours en malherbologie offert à I'Université Laval.

- En 1970, le premier cours en malherbologie offert aux agronomes des régions agricoles du Québec était préparé et présenté sous sa direction.

- En 1971, sa carrière de gestionnaire débutait comme directeur du Service de recherche en défense des cultures du MAPAQ. De plus, en 1972, il était le président-fondateur de la Commission de malherbologie du Québec, ceci tout en assumant la fonction de président de la SPPQ de 1972 à 1973.

- Enfin, de 1992 à 1994, il devenait cadre-conseil à la Direction de la recherche et du développement du MAPAQ.

Par ailleurs, l'implication de Monsieur Émond dans le monde de l'édition et de la diffusion des informations scientifiques en protection des plantes ne date pas d'hier. Ses contributions ont pris diverses formes au fil du temps.

- En 1975, il élaborait la structure du Réseau d'avertissements phytosanitaires du Québec et il en a assumé la gestion pendant 17 ans.
- En 1985, à titre de directeur du Service de phytotechnie de Québec, il veillait à la mise en place du Laboratoire de diagnostic en entomologie, malherbologie et phytopathologie du MAPAQ.

- En 1995, Monsieur Émond acceptait de relever le défi que lui proposait la SPPQ et devenait rédacteur en chef de la revue Phytoprotection.

Pour accomplir cette tâche, Monsieur Émond pouvait compter sur ses nombreuses expériences: il avait été rédacteur associé en malherbologie pour Phytoprotection de 1980 à 1984 ainsi que rédacteur en chef de la $3^{e}$ édition du volume Nom des maladies des plantes au Canada publiée par la SPPQ en 1992 et de la réimpression de la $3^{e}$ édition corrigée en 1996. Par surcroît, au cours de sa carrière au MAPAQ, Monsieur Émond avait coordonné la rédaction et la publication de quelques guides et manuels, tels que les manuels de lutte contre les ennemis des cultures, de même que des feuillets de l'Atlas sur les ennemis des cultures. Il avait également supervisé la mise en place de systèmes-experts pour l'aide au diagnostic et à la prise de décision en malherbologie et en phytopathologie.

Monsieur Émond a entrepris son travail de rédacteur en chef de Phytoprotection avec la même attitude qui l'avait caractérisé au cours de sa carrière au MAPAQ. Il s'est impliqué à fond, a travaillé rigoureusement, a pris les décisions et a posé les gestes qui s'imposaient pour assurer la bonne marche de la revue, l'une des plus anciennes revues scientifiques en protection des plantes en Amérique du Nord.

Du premier numéro du volume 76 , publié sous sa direction en avril 1995, au troisième numéro du volume 85, publié en juin 2005, Monsieur Émond a supervisé la révision de quelques centaines de manuscrits, dont près de 110 ont été publiés. II a également orchestré la publication de 50 communications de symposiums et des résumés de 15 réunions annuelles de sociétés savantes.

Monsieur Émond a coordonné le travail rémunéré d'un rédacteur technique et d'une adjointe technique pour la préparation des épreuves prêtes à être imprimées. Il a également dirigé le travail d'un webmestre pour la création du site Web de la revue. De plus, son équipe d'édition comptait plusieurs bénévoles, dont près d'une douzaine de rédacteurs associés et plus d'une soixantaine d'experts réviseurs 
dans les sphères d'activités couvertes par la revue. Pendant 10 ans, il a recruté des rédacteurs associés et a entretenu de nombreux échanges avec les auteurs, les rédacteurs associés et la rédaction technique. Monsieur Émond est intervenu fréquemment auprès des fournisseurs de service de photocomposition, d'impression et de messagerie postale. Finalement, Monsieur Émond et moi avons communiqué de façon régulière pour assurer le suivi de la gestion financière de la revue. Inutile de préciser que la première décennie de sa retraite du MAPAQ a été très occupée.

C'est sous l'impulsion de Monsieur Émond que les membres du comité de rédaction ont convenu, en 2003, de modifier le format, I'apparence et le contenu de Phytoprotection afin de rendre la revue plus attrayante auprès du lectorat et d'augmenter le nombre d'auteurs susceptibles de soumettre des manuscrits. Ainsi, aux articles scientifiques originaux, aux communications brèves et aux articles de synthèse se sont ajoutées plusieurs nouvelles rubriques : les nouvelles avancées, les forums de discussion, les profils scientifiques, les mini-synthèses, les technologies émergentes et les notes en protection des plantes. Je vous invite à prendre connaissance de la description et du contenu de ces nouvelles rubriques dans chacun des numéros du volume 85 .

La SPPQ est très redevable à Monsieur Émond pour les excellents états financiers de la revue puisqu'il a investi beaucoup d'efforts à rechercher et à obtenir des subventions auprès, entre autres, du Fonds de recherche sur la société et la culture (FORSC) et de Patrimoine Canada. II a aussi obtenu plusieurs commandites auprès du MAPAQ et d'autres ministères ou organismes. Depuis 1995, Monsieur Émond, appuyé par certains de ses collaborateurs du comité de rédaction, a recueilli plus de 135000 \& en subventions et en commandites. À titre de trésorier, j'ai secondé Monsieur Émond pour la préparation des demandes de subvention du FQRSC pour les années 2002-2005 et 2005-2008 et l'aide totale accordée a fourni près de 106000 \$. Cet apport financier a permis de produire la version numérique de Phytoprotection et d'en soutenir les efforts de diversification du contenu éditorial. Ainsi, tous les numéros parus depuis le volume 84 (2003) peuvent être consultés via le site Web Érudit à l'adresse suivante :

http://www.erudit.org/revue/phytoprotection.

La SPPQ a également bénéficié du dévouement de Monsieur Émond qui a mené à bien l'exigeant travail de la $4^{\text {e }}$ édition du volume Nom des maladies des plantes au Canada, publiée en 2003. Tout au long de ses mandats, Monsieur Émond a démontré beaucoup de leadership et une ferme volonté de motiver tous ses collaborateurs afin que ces publications (revue et volume) paraissent dans les délais souhaités.
En 1993, la SPPO désignait Monsieur Émond membre honoraire de la Société. Son dévouement, son leadership et ses nombreuses réalisations en protection des plantes ont également été soulignés par la Société canadienne de phytopathologie qui I'a nommé membre honoraire en 1996. De plus, en 1999, I'Ordre des agronomes du Québec lui a décerné le titre de Commandeur de l'Ordre du mérite agronomique.

Ainsi, au nom de la Société de protection des plantes du Québec, j'ai l'honneur et le plaisir de remercier très chaleureusement Monsieur Gilles Émond d'avoir consacré bénévolement autant de temps et d'énergie pendant une décennie à superviser et coordonner I'édition et la production de la revue Phytoprotection, à en faire sans relâche la promotion auprès des auteurs et des lecteurs potentiels ainsi qu'à rechercher le soutien financier de plusieurs organismes gouvernementaux.

Richard Hogue, trésorier de la revue Phytoprotection, est chercheur en phytopathologie à I'Institut de recherche et de développement en agroenvironnement (IRDA) à Québec.

À la suite de cette allocution, Madame Vicky Toussaint, présidente de la SPPQ, a présenté à Monsieur Gilles Emond une attestation de la gratitude que la Société lui reconnaît pour sa contribution dévouée au rayonnement de la revue Phytoprotection. 


\section{Tribute to Dr Gilles Émond}

Opening address given by Mr Richard Hogue as an homage to Mr Gilles Émond for his services as Editor-in-chief of the journal Phytoprotection during the 97th annual meeting of the Quebec Society of Plant Protection (OSPP) held on June 9 and 10, 2005, in Gatineau, Quebec, Canada.

I thank the Board of Directors of the OSPP for the opportunity to pay tribute to Mr Gilles Émond for his ten years of volunteer work as Editor-in-chief of Phytoprotection.

These few biographic notes will first help you get better acquainted with Mr Émond, as a scientist and a manager:

- After having completed his degree in agronomy at the University of Montreal in 1958, Mr Émond began his career as civil servant at the Ministère de I'Agriculture, des Pêcheries et de l'Alimentation du Québec (MAPAQ), where he worked for 36 years.

- From 1962 to 1968, he successively completed his Master's and Ph.D. degrees at McGill University in weed science. His Master's thesis dealt with the mode of action of linuron used in pre-emergence, while his Ph.D. thesis was entitled: The absorption and distribution of linuron in kidney bean and its mode of action on photosynthesis and respiration.

- In 1965, Mr Émond played a major role in devising and presenting the first course in weed science at Université Laval.

- In 1970, the first course in weed science offered to agronomists working in the rural regions of Quebec was conceived and given under his supervision.

- In 1971, he started his career as manager when he became Director of the Service de recherche en défense des cultures du MAPAQ. In 1972, he became the founding president of the Commission de malherbologie du Québec (Quebec Weed Commission), and he was also president of the QSPP in 1972 and 1973.

- Finally, from 1992 until 1994, he held the position of functional manager at the Direction de la recherche et du développement du MAPAQ.

Mr Émond's involvement in the edition and dissemination of scientific information on plant protection has been going on for a long time. His contributions over the years have taken on diverse forms:

- In 1975, he conceived the organizational structure of the Réseau d'avertissements phytosanitaires du Québec, and he managed this service during 17 years.

- In 1985, as the Director of the Service de phytotechnie de Québec, he devised and supervised the start-up of the Laboratoire de diagnostic en entomologie, malherbologie et phytopathologie du MAPAQ.
- In 1995, Mr Émond took up the challenge addressed to him by the QSPP and agreed to be Editor-in-chief of Phytoprotection.

To carry on this task, Mr Émond could rely on his numerous past experiences as associate editor in weed science for Phytoprotection from 1980 to 1984 and as editor of the 3rd edition of the book Names of Plant Diseases in Canada, published in 1992, and of the 3rd revised edition, reprinted in 1996. During his career at the MAPAQ, Mr Émond coordinated the copywriting and publishing of a few guides and manuals, such as the manuels de lutte contre les ennemis des cultures, and also some fact sheets of the Atlas sur les ennemis des cultures. He also supervised the development of expert-systems to provide support for diagnostic and decision making in weed science and phytopathology.

Mr Émond undertook his appointment as Editorin-chief of Phytoprotection the same way he led his career at the MAPAQ, namely by being highly involved, working hard, making tough decisions and by doing what he had to do to ensure the smooth running of one of the oldest North American scientific journals in plant protection.

From the first issue of Volume 76, published in April 1995, until the third issue of Volume 85, published in June 2005, Mr Émond supervised the editing of several hundred manuscripts, of which nearly 110 have been published. He also coordinated the publication of 50 symposium communications and the abstracts of 15 learned societies' annual meetings.

Mr Émond supervised the paid work of a technical editor and a copy editor in order to edit the proofs ready to be printed. He also coordinated the work of a webmaster for the Phytoprotection Web site. His editorial team was comprised of many volunteers, including a dozen associate editors and around sixty experts in plant protection for the peer review process. During ten years, he recruited several associate editors and he has been in contact with many authors, associate editors and members of the Editorial Board. Also, Mr Émond was frequently in touch with service providers for photocomposition, printing and courier services. Finally, Mr Émond and I discussed regularly about the financial management of Phytoprotection. Needless to say, the first decade of Mr Émond's retirement from MAPAQ has been quite busy. 
The members of the Editorial Board, driven by $\mathrm{Mr}$ Émond, agreed in 2003 to modify the format, the presentation and the content of Phytoprotection to enhance its appeal to subscribers and increase the number of authors who submit their manuscripts. Many new columns have been added to the original scientific papers, short communications and review papers, such as research breakthroughs, forums, scientific profiles, mini-reviews, emerging technologies and notes in plant protection. I invite you to learn more about the content of these new columns by looking up each issue of Volume 85.

The QSPP is indebted to Mr Émond for the excellent financial statement of Phytoprotection, since he devoted many efforts to seeking and obtaining grants from the Fonds de recherche sur la société et la culture and Canadian Heritage, among others. He obtained many sponsorships from the MAPAQ and other departments or organisations. Since 1995, Mr Émond, supported by some of his collaborators from the Editorial Board, collected more than \$135,000 in revenue from grants and sponsorships. As treasurer, I collaborated with Mr Émond to the submission of grant applications to the Fonds de recherche sur la société et la culture for the periods 2002-2005 and $2005-2008$, and these grants totalized about $\$ 106,000$. This amount allowed the implementation of the electronic format of Phytoprotection and they supported the efforts to diversify the editorial content of the journal. Therefore, all issues that have been published starting with Volume 84 (2003) can be consulted on the Web site Érudit at:

http://www.erudit.org/revue/phytoprotection.

The QSPP also benefited from the dedicated work of Mr Émond who has achieved the demanding task of editing the 4th edition of the book Names of plant diseases in Canada, published in 2003. During his mandates, Mr Émond showed great leadership and a strong commitment to motivate all his collaborators so that the issues of Phytoprotection and the book Names of Plant Diseases in Canada be published in due time.

In 1993, the QSPP made Mr Émond an honorary member of the Society. Mr Gilles Émond's dedication, leadership and numerous achievements in plant protection have also been appreciated by the Canadian Society of Phytopathology which made him honorary member in 1996. Also, the Order of Agrologists of Quebec awarded him the title of Commandeur de l'Ordre du mérite agronomique in 1999.
On behalf of the Quebec Society of Plant Protection, I am honoured and pleased to warmly thank Mr Gilles Émond for having voluntarily devoted so much of his time and energies during the past decade to supervising and coordinating the edition and publication of Phytoprotection, promoting restlessly the journal to potential authors and subscribers, and also seeking and obtaining grants and sponsorships from several governmental agencies.

Richard Hogue is Phytopathologist at the Institut de recherche et de développement en agroenvironnement (IRDA) in Quebec City, and he is the treasurer of Phytoprotection.

After the address, Ms Vicky Toussaint, chair of the QSPP, presented a gift to Mr Gilles Émond to express the Society's gratitude for his devoted contribution to the renown of Phytoprotection. 